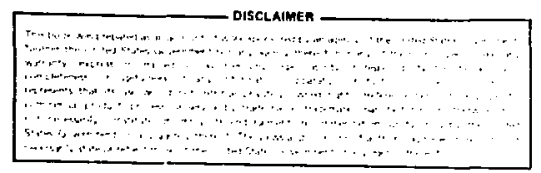

SAND76-0438 Revised

Distribution

Unlimited Release

Category UC -41

Printed March 1981

(Supersedes SAND76-0438 dated May 1979)

\title{
A Guideline for the Preparation of Safe Operating Procedures
}

\author{
Lee Stinnett \\ Margaret M. Carroll \\ Debra L. Crooks \\ Joseph R. Doyle \\ Harold G. Jeblick \\ David S. Kessel \\ Marshall W. Tippy \\ Johnny M. Stuckey \\ Safety Standards and Engineering Department \\ Sandia National Laboratories \\ Albuquerque, New Mexico 87185
}

\begin{abstract}
Sandia National Laboratories' Safe Operating Procedures are written for activities that involve the use of explosives, dangerou chemicals, radioactive materials, hazardous syatems, and for certain types of operational facilities which present hazards. This guideline presents a suggested Safe Operating Procedures format.
\end{abstract}




\section{A Guideline for the Preparation of Safe Operating Procedures}

\section{Introduction}

This guideline for the preparation of Safe Operating Procedures (SOP) presents a suggested SOP format. With the exception of the cover sheet (which is the signature approval sheet), the sign-off sheet for employees authorized to operate under the provisions of the SOP, and the assignment of the SOP control number, the originator of an SOP has the prerogative of incorporating all or portions of the suggested contents and format, depending upon the technical requirements, organizational procedures, and literary preferences of the author.

Safe Operating Procedures should be prepared for activities that involve the use of explosives; dangerous or potentially injurious chemicals, radioactive materials, hazardous systems, high-pressure and high-vacuum systems, and certain types of routine operational facilities. The publications listed below state the safe:y policy of Sandia National Laboratories concerning SOP's:

1. Industrial Safety, Fire Prevention and Fnvironmental Health Manual. SC-M-70-889

2. Pressure Safety Practices Manual, SAND76-0424 (Revised)

\section{The Need for an SOP}

Questions concerning the need for an SOP should be directed to the safety consultant for your organization. If the quertions concern radioactive or toxic materials, lasers, nuise, or microwaves, the questions should be directed to the Environmental Health Department. Do not use the format described in this manual for SOPs for which the Environmental Health Department has sole approval authurity. Their requirements and format vary from those outlined here. SOPs that have a mix of hazardous elements (such as the areas listed above that Environmental Health is responsible for) with elements such as pressures, high electrical energy R\&D systems, high temperatures, explosives, etc, must be reviewed by both Environmental Health and Safety Engineering.

\section{Importance of an SOP}

The importance of abiding by a written Safe Operating Procedure cannot be overemphasized. A direct correlation exists between a good SOP, conscientiously followed, and a safe operation. Presence of an SOP before the start of an operation involving hazardous material, processes, or conditions normally assures that the operation has been edequately evalunted, hazards identified, risks asmesmerl, and that neceasary safepuarda have been eatabliohed. If an acceptable SOP is approved for a hazardous operation, the following have been accompliahed:

1. The person responaible for planning or conducting the teat or operation has reviewer the complete projact. The SOP then reflects the plans and operational requirementa in a concise, complote, and logical mannor.

2. The procedure for conducting the operation is firmly eatabliahed. The responeible person will not be ieving inatructions haphazardly. Thus, the powibility of omittins an important step and causing hazard comequencen will be reduced because a logical sequones of operatione will be follomid. 
3. Careful thought was given to the safest location, the number of persons required, and the proper equipment needed for the test.

4. Thought was given to how the work will affect the health and safety of operating personnel as well as others who may be in the vicinity of the operations.

5. More than one person have reviewed the operation - each with his own perspective. Consequently, more safeguards will be considered, with the result that there is less likelihood of omitting an important safety consideration.

6. The presence of a carefully prepared SOP, which should have heen reviewed before the test or operation, has reduced the possibility of someone giving or following impulsive or improper instructions.

7. Procedures have been established for the necessary actions in case of an abort, misfire, power failure, or other contingency.

Normally no deviation is permitted from the requirements of an SOP unless agreed to by all persuns with signature authority for that SOP. If major functional changes are necessary for the operation, the SOP shall be revised and approved before the implementation of any changes in an operation. SOPs are reviewed at least once every 12 months to assure that they are adequate, that personnel lists are current, that new lications and equipment are authorized, that test sequences are up to date, and that SOP procedures are being followed correctly (see paragraph XI).

Safety may require a major review and rewrite of SOPs that are more than 3 years old. SOPs that are more than 1 year old should be reissued if management, authorized personnel, hazardous materials, or site locations are changed. Inactive SOPs that may be reactivated should be kept on file by the uriginating organization.

\section{Control Numbers and Approvals}

The Safety Engineering Division arsigns a control number to each SOP. For Example. the control number may appear as 070008309.

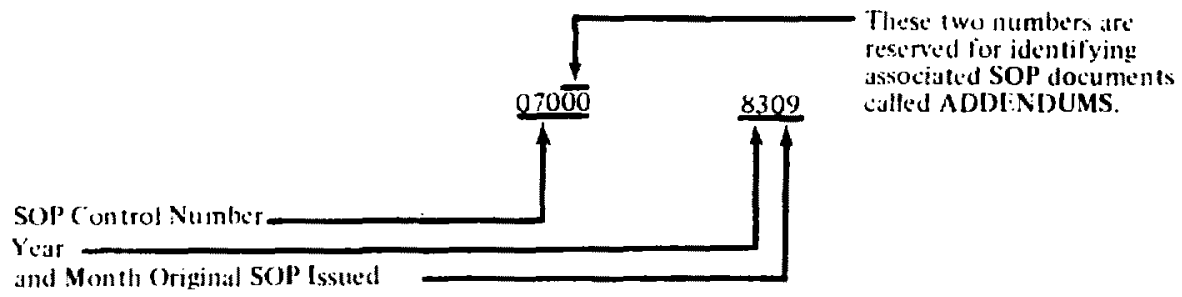

A new SOP control number and date will be issued whenever major ch $: \cdot$ ges are made and when new signature approvals are ubtained. All signatures are secured before the SOP is routed w the Safety Engineering Division for approval. After all approval signatures are obtained, an SOP is distributed hy the responsible line organization.

\section{Writing an SOP}

The following pares contain item-by-item discussions of the production of an SOP. Normally, for quick identification purpomes, an SOP is covered with a special distinctive cover (SC2039C), that is available from Safoty. The use of this yellow cover and its matching back cover is optional. It is halpful to have the cover on copies of an SOP that are retained in the laboratory near the teat equipment it refers to. These covers need not be placed on file copies nor do they need to be placed on copies beine distributad to the Safoty Engineering Division and/or Environmental Health Department. 
SOP Number (Assigned by Safety)

Original Issue or Supersedes (SOP No.)

Originating Organization Number

Use oniy when issuing an addendum. See Section IX for correct usage.

Location of die-cut window in cover sheet; see last paragraph on prior page

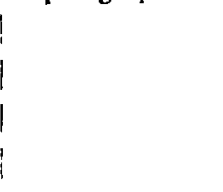

\section{ADDENDUM \\ for \\ (Title of Operation) \\ at}

SAFE OPERATING PROCEDURE

(Location or Facility)

(If appropriate

(Provide an abstract in this space that will succintly describe the purpose of the operation, test, etc, and include all of the hazards that may be encountered.)

(This page shows the format for the title page of all SOPs. Changes may be made as necessary, but the location of the SOP number, title, preface, approvalsignatures, and distribution should be maintained. Format and sequence of signatures are optional. Additional signatures and distribution may be carried over to Page 2.)

(Line Department Manager)

$$
\text { Approved }
$$

Date

(Line Sup. of Orig. Org.)

\begin{tabular}{c}
$\begin{array}{c}\text { Approved } \\
\text { (Author) }\end{array}$ \\
\hline $\begin{array}{c}\text { Signed } \\
\text { Presure Advisor** }\end{array}$ \\
\hline
\end{tabular}

(Approved)

\begin{tabular}{l} 
Date \\
\hline Date \\
\hline Date
\end{tabular}

(Safety Engineering Div.Sup.)

$$
\text { Approved }
$$

Date

Industrial Hygiene Div. Sup. or Health Physics Div. Sup.)*

$$
\text { Approved }
$$

Date

Safety Enginecr

$$
\text { Approved }
$$

Date

Date

"List only if Environmental Health approval is jointly required with that of the Safety Orzanization.

"List only if SOP has pressure elements as defined in Sand76.0424 (Revised).

**Approval signatures are required for all orzanizations having people or facilition involved in operation covered by an SOP.

\section{Distribution:}

\section{Using Orranization:}

Induatrial Hyrione and/or Hoalth Phyeics (if approved by)

Safoty Engineoting Division

Othars as detormined by author 


\section{Safe Operating Procedure for (Title of Operation)}

It is intended that the author have flexibility in the preparation and selection of format and contents for the SOP. The following is offered as a suggested guideline for format and content.

I. References

Indicate the old SOP Number if this SOP is a supersession. List associated site SOP, if any. Reference appropriate DOE, Military, or Sandia National Laboratories memoranda manuals, Pressure Safety Analysis Reports, directives, standards, engineering drawings, specifications, source documents, equipment manuals, manufacturers' manual, etc. Since an SOP is a working document, it is preferable that references be part of the SOP package as an enclosure or an appendix. Pertinent abstracts of other source documents can be made appendices of the SOP or, if appropriate, they may be included in the SOP itself.

II. General or Introduction

The opening section contains all related nontechnical information. This includes the scope of the SOP, purpose of test, results expected, requirements governing activities at other locations, SOP review requirements, and special training and qualification requirements for operating personnel.

Examples:

A. Brief description of test, process, or operation and the objectives sought

B. Location of the assembly, test, or operation.

C. Organization involved (number and name). Include other goverumental and manufacturing participants.

1I1. Hazards - Types, Sources, and Associated Characteristics (consider impact on environment)

A. Toxics: Chemicals, solvents, mixtures, acids, caustics, vapors, gases, airborne pollutants, reactions with other materials, etc. (Refer to Environmental Health Section of SC-M-70889.)

B. Flammables and Combustibles: Liquids, vapors, gases, fibers, dusts, and compounds, etc. (Refer to Fire Prevention Section of SC-M-70-889.)

C. Explosives (This includes High Explosives, Propellants, Ammunition, Pyrotechnics, and chemical explosives): Nomenclature, types, sizes, weights, combinations, sensitivity, chemical and/or physical description, mechanical functions, and electrical characteristics (electrostatic) etc. (Refer to Explcsives portion of Industrial Safety Section of SC-M-70. 889; SLI6971-Storage and Disposal of Explosives; SLI2045-Hazardous Materials Transportation.)

D. Missiles: Fragments, pellets, rocks, dust particles, bullets, blanks, etc.

E. Pressure: Overpreawure, blast pattern, shrapnel, high velncity jets, compressed gases/iquids, etc. List appropriate, Pressure Safety Analysis Reports (PSARs) if not listed in the References. (Refer to the Preasure Safety Practices Manual, SAND76-0424 (Revised). Consult your oreanizational preseure advieor.)

F. Temperaturen: Low iemperatures, high tomperatures, heat cauced by burned fuel, solar, of electricity, stam, etc.

G. Bquipment: Movin parts, voltare cources protected, code requirementu met, adequate cuards, fail-wafe features, overload conditions, braken, gasoline ve electrically powered, otc.

H. Material: If material compatibility is an important feature of the syntem, include detaile of moterials to be used and why, etc. 
IV. Handling Precautions

A. Gentral: Handling, transportation, and storage procedures; load limits, limitations on buildings, storage period, peruonnel limits, safe separation distanass, etc.

B. Grounding: Static electricity, electric tools, test equipment, correct polarity, use of GFCI, etc.

C. Special: Precautions unique to materials used, handling, environment, temporary storage, surveillance, containment fix tures, missile barriers, etc.

*D. Special Equipment: Special escembly and handling fixtures, special tools, gauges, wrist strapa, fire ertinguinhers, ladders, scaffolds, etc.

*E. Testing Equipment: Alinco Igniter Circuit Tester shall be used to check EEDs unless other equivalent devices are authorized for specific operations.

*F. Personnel Protective Gear: Clothing (arctic, tropic, underground, laboratory), glasses, face shields, breathing apparatus, doaimeter badges, hearing protective devices, etc.

*G. Environment: Overhead electrical wires, safe separation distances, shock waves, noise, toxics, nonionizing and ionizing radiation, aircraft, heat, cold, dust, wind, solar reflection, etc.

V. Emergency Procedures

Procedures should be defined for corrective actions to be taken if emergencies, technical mishaps, accidents, misfires, aborts, equipment and power failures, etc, occur. Actions concerning injured persons; cleanup of apills; placement of barricades; notification of supervision, Safety, Security, and Plant Engineering; follow-on investigation, and subsequent report (if required) should be considered and specified.

VI. Asembly Procedures

Be brief but adequate. Include, if appropriate, the what, how, where, when, who, and why of ancmbly. Indicate safety requirements, limits, restraints, tolerances, etc.

VII. Authorized Personnel

List persons in charge (i.e., project leader, range officer, technician, etc) who will be responsible for seeing that all provisions of the SOP are observed. Name those approved to handle explowives and other dangerous materials. Include a sign-off sheet which indicates that the authorized persons involved have read the SOP, understand it, and will work within its constraints.

NOTE: Special emphasis is placed on the requirement for in-depth training of new hires or tranaferees before they are authorized to perform the functions covered by any SOP.

VIII. Other

Helpful sugsestion, advice, cautions,and any other comments that will make the SOP more effective should be included.

IX. Enclasures

A. Exhibita, which are unually numbered, may be grouped in the "Exhibit Section," or placed throughout the text immediately after the point where they are mentioned. Exhibits and illuatrations senorally are used to clarify or demonstrate certain points in the procedure. They aleo may be uned as references. They may include

1. Schomatic

2. Drawinge

3. Documents

4. Photograph

5. Procedure of instructions

6. Mape

"See Article IX, Section B, concerning optional procedure for inclusion in SOP. 


\section{B. Appendices}

Appendices, which are usually lettered, include supplemental information too detailed or lengthy to be included in the main body of the text. They may consist of lists of required equipment, safety checks, authorized personnel, protective clothing, safety equipment, communication equipment, tools, etc.

X. Addendums

Addendums are approved supplemental information issued after an SOP has been distributed. The addendum may be issued to authorize a specific type of test, a one-time test, add or delete authorized personnel, or it may authorize the use of additional sites and facilities.

Addendums are issued in the same format as shown on page 4. The word "ADDENDUM" shoula be added above the SOP title. Place the addendum information above the signature requirements; use additional pages if necessary. Minimal signature level requirements are the same as for the original SOP unless the original SOP specifies divisional signature only for addendums.

Addendums require a discrete control number which is assuciated with the parent SOP. The number is assigned by the Safety Engineering Division. For example, an SOP issued in September 1983 might have the control number

\section{9}

If for instance, one month later, Addendum No. 1 were issued, it would be numbered 070018310

and if, 13 months later, Addendum No. 2 were issued, it would be numbered 070028411

Addendums should be attached to all copies of the original SOP whether they are located in the lab, assembly area, test cell, or office file.

Organization numbers are not a part of the official SOP number but are used for identification purposes in computer input, filing, etc.

\section{Annual SOP Review}

SOPs must be reviewed annually. Originating organizations are notified by their safety consultant, usually during the month the review is due. Methods of certification of review may vary, but usually a dated form attesting to review and signed by the line organizational and safety representatives is sufficient provided distribution copies are filed with the SOP (and addendums, if any). Original issue and review dates are recorded by the Safety Department; the computer printouts are the suurce of the review dates provided to the SOP-originating organizations. SOPs that are no longer needed for active use should be cancelled by notifying the safety consultant. SOPs which are not used but may be used in the future can be identified as inactive (I). SOPs 80 identified must be reviewed, updated, and made active (A) prior to use. 